\title{
Suggestion of Model Change Work Improvement by REBA and Therblig
}

\author{
Sung Koon Lee, Peom Park \\ Department of Industrial Engineering, Ajou University, Suwon, South Korea, 443-749
}

\begin{abstract}
Objective: The aim of this study was to provide a method to improve the compliance and reduce the time by reducing the workload during the model change work. Background: The enterprises are constructing the small quantity batch production system by increasing the number of model change and reducing model-changing. However, the compliance is low because the work is strenuous and high skills are needed, so the system management is facing with many difficulties. Method: After classifying the model change work according to the purposes(preparation, change and adjustment) with the target of mascara filling machine, element tasks time were measured and the motion analysis(therblig symbol) and REBA analysis were performed. The study incorporated 3 independent variables as the number of motion, REBA score and the element time. The dependent variable is the type of element work as preparation, change and adjustment. The statistical test was performed by one-way ANOVA $(\alpha<0.05)$. Results: For the preparation, the number of motions appeared in the order of Use(U), Transport Loaded(TL), and Position(P). The order appeared in change is Use(U), Release Load(RL), and Grasp $(\mathrm{G})$. The adjustment appeared in the order of Position(P) and Use(U). The results of average motion time as the element work times divided by the number of motion appeared in the order of adjustment $(1.85 \mathrm{sec} / \mathrm{motion})$, preparation( $1.11 \mathrm{sec} /$ motion), and change( $0.62 \mathrm{sec} /$ motion). The results of REBA showed that the average risk level of change and adjustment were medium, but $53.1 \%$ of change and $42.9 \%$ of adjustment were evaluated as high. Conclusion: Reducing the avoidance and improving the compliance of work could be expected if the job autonomy were improved by improving the working postures with high risk level. Application: It is expected to solve the problem of reducing the time of model change work in the small quantity batch production system. The future work is to carry out the improvement directions found in the results and compare the results after improvement.
\end{abstract}

Keywords: Model change, Therblig, REBA, Preparation, Change, Adjustment

\section{Introduction}

고객이 요구하는 제품 품종이 다양화 되면서 경영자는 생 산부문에 대하여 납기 대응과 제조 리드 타임 단축을 위해 시스템 변화를 요구하고 있다. 또한 시스템 변화 시 재공 재 고 감소와 가동률 향상을 전제로 다품종 소량 또는 변종변량 생산시스템 운영 방법을 추구하고 있다(Kim and $\mathrm{Kim}$,
2005; Koo et al., 2005). 단일 라인 또는 공정, 설비에서 생 산되는 많은 제품종류와 그 순서에 따라 시간 차이가 크기 때문에 다품종 소량, 변종변량 생산시스템에서 준비교체 시 간은 중요 관리 항목 중 하나이다(Kim and Kim, 2005). 준비교체 시간 차이가 클 경우의 문제점은 첫째로 공정간의 계획된 일정으로 공급하지 못하는 공급일정 미 준수가 발생 한다. Choi et al. (2001)은 불완전한 생산 공정하에서의 경제 적 로트 일정계획 문제에 관한 연구에서 Ben-Daya and 
Hariga(2000)이 제시한 공동주기 방법과 시변 로트 크기 방법을 사용한 결과, 준비교체 시간이 존재할 경우 적합성 검증이 복잡하다고 하였다. 이는 공급일정 준수를 위해서 준 비교체 시간을 위한 일정량의 재고를 보유하게 되고, 납기 대응을 위한 제조 리드 타임 단축과정에서 준비교체 시간도 설비 고장시간과 같이 동일한 제약조건으로 발생하여 재공 재고를 증가시키는 요인이 되기 때문이다. 둘째로는 다품종 소량 생산순서를 준수하면 가동률 저하가 발생한다. 이는 소 품종 대량생산 시스템보다 준비교체 횟수가 증가되어 설비 의 6대 Loss 중 준비교체 시간이 늘어나 가동률 저하의 요 인이 되기 때문이다(Ham, 2000). 셋째로 준비교체 횟수 증 가 시 감독자와 작업자의 준비교체 시간 준수율 저하와 기피 현상이 발생한다. 이 현상은 $\operatorname{Kim}(2009)$ 이 연구한 직무 스 트레스와 근골격계 작업 부담간의 연관성 분석에서 직무 자 율성이 부담 작업자보다 비 부담 작업자가 더 높게 나타난 다고 연구된 결과와 동일하다. 따라서 준비교체 작업의 시간 단축은 변종변량 생산시스템을 구축 및 운영하는데 있어서 중요한 개선 항목 중 하나이다.

Kim and Lee(2001)는 공정교체 시간을 고려한 배치작업 의 일정계획 연구에서도 일정기간 내에서 전체 준비교체 시 간을 최소화하는 목적으로 연구되었다. 이는 각 준비교체 시 간의 합이 클 경우에 적용할 수 있는 연구로 다품종 소량과 변종변량의 단 납기 생산시스템에서 요구하는 횟수 증가에 따른 제약조건에 어려움이 있다.

도요다 생산시스템에서는 준비교체 시간을 9분 이내로 개 선(싱글 단도리)하는 것을 요구한다(Shingo, 1989). 개선 순서로 첫째, 준비교체 시간영역 내의 작업(內 準備)을 설비 가동 중에 사전 준비화(外 準供)시키는 방향으로 개선할 것. 둘째, 준비교체 작업을 준비, 교환, 조정작업으로 분류하고 개선하기 쉬운 준비작업 개선부터 실시할 것. 셋째, 교체와 조정을 개선할 것으로 전개하고 있다. 이러한 준비교체 작업 개선에 관한 연구들은 개선 대상과 우선순위 결정을 시간 단 축에 목표를 두고 있다. 하지만 이 과정에서 준비교체 작업 수행 중 작업부담으로 인한 위험수준은 객관적으로 고려되 지 않고 있다.

따라서, 본 논문의 목적은 준비교체 작업을 준비, 교체, 조 정의 세 가지 요소작업으로 분류하여 각 요소작업에 대한 동작분석(서어블릭 기호), 시간측정, $\mathrm{REBA}$ 분석을 통해 준 비교체 작업을 효과적으로 수행하기 위한 개선 방법을 제시 하는데 있다. 이와 같은 연구를 통해 준비교체 작업의 부하 요소를 찾고 이를 감소시키면 준비교체를 효과적으로 수행 할 수 있다. 또한 비 부담작업으로 직무의 자율성이 높아져 준비교체의 기피 현상 감소와 준수율 향상으로 다품종 소량 생산의 제약조건을 감소시킬 수 있을 것이다.

\section{Method}

\subsection{Procedure}

연구 절차는 Figure 1 의 동작, 시간분석에 따른 작업부하 평가 절차와 같이 선정된 공정의 준비교체 작업을 현상조사, $\mathrm{VCR}$ 촬영, 작업분석, 시간측정, $\mathrm{REBA}$ 측정, 통계분석 순으 로 실시하였다. 화장품 제조업에서 마스카라 제품의 충진 공 정 설비를 대상으로 현상조사에서는 3 개월간의 생산 실적 데이터를 근거로 주간 단위 생산 품종 수, 가동률 및 준비 교체 현황을 파악하였다. 준비교체 시간은 $\mathrm{A}$ 제품의 생산이 끝나고 $\mathrm{B}$ 제품 생산이 되는 시점까지의 시간으로 정의한다 (Shingo, 1989).

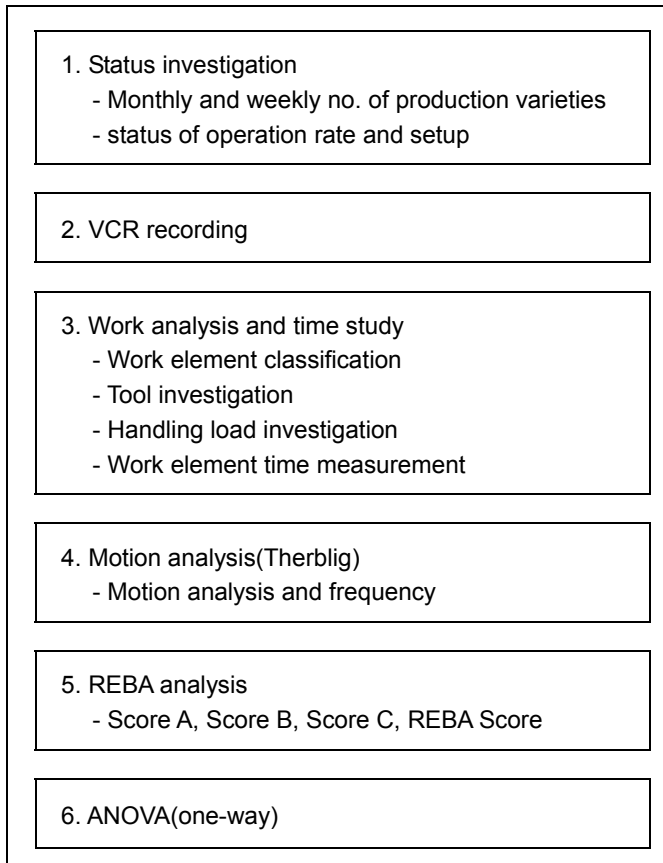

Figure 1. The process of workload evaluation of motion, time analysis

$\mathrm{VCR}$ 촬영은 $\mathrm{A}$ 제품 생산 완료 시점부터 $\mathrm{B}$ 제품 생산 시작 시점까지의 준비교체 작업 실행과정을 캠코더로 촬영하였다. 작업분석은 요소작업 분류와 사용도구를 측정하였고, 시간측 정은 요소작업 기준으로 시간관측을 실시하였다. $\mathrm{REBA}$ 측 정은 작업분석에서 분류된 요소작업 내용 중 대표 작업자세 를 선정하여 Score A, Score B, Score C, REBA Score순 으로 측정하였다(Hignett and McAtamney, 2000). 통계 분석은 Minitab 14 (Minitab INC.)을 이용하여 일원배치 분 산분석을 실시하였다. 


\subsection{Field research}

대상 공정은 화장품 마스카라 충진 설비로 내용물 제조 후 포장라인 공정 중 첫 번째 공정이며 라인 준비교체 시 가장 시간이 많이 소요되는 공정이다. 이 공정을 대상으로 생산 실적 3 개월 동안의 생산실적 현황을 조사한 결과 생산일수 는 53일, 품종 수는 34종이며, 1일 1종에서 5종까지 생산 하였다. 총 부하시간은 16,996 분으로 총 고장시간이 73 분, 총 준비교체 시간은 1,767 분, 총 횟수는 86 회로 파악되었 다. 이를 시간 가동률과 준비교체 Loss율로 계산하면 각각 $89.2 \%$ 와 $10.4 \%$ 로 조사되었다. 평균 1 회 준비교체 작업시 간은 20.6 분으로 최대 73 분, 최소 5 분이었다. 표준 준비교 체 작업시간은 20 25분으로 내용물 교체, 용기 교체, 팩킹 교체, 브러시 캡(바르는 도구) 교체의 작업내용으로 이루 어진다. 또한 준비교체의 작업내용 구성은 차기 생산 제품 의 판매 향(국내 및 나라별 수출), 브랜드에 따라 구성된다 (Table 1). 즉, 1 가지부터 4 가지 작업내용이 발생하지만 작 업내용 별로는 방법과 순서는 동일하며 준비교체 작업시간의 차이는 사용한 작업내용에 따라 달라진다. 예를 들어 최소시 간 5 분의 경우는 용기를 교체하기 위한 지그 $(\mathrm{Jig})$ 교체이다. 표준 준비교체 작업시간을 초과하는 시간부터 최대 73 분에 대한 대부분의 사유는 작업 방법과 순서를 제외한 관리상의 문제이며 특별한 사유 없이 발생하는 미 준수 시간이었다.

Table 1. Change work of products(based on order of product)

\begin{tabular}{c|c|c|c}
\hline Brand & Sales & Product Name & Change work \\
\hline Hooo & Domestic & No.79 $(11 \mathrm{ml})$ & 2 \\
\hline Mooo & Foreign & No.79 $(11 \mathrm{ml})$ & $1,2,4$ \\
\hline Mooo & Foreign & No.79 $(08 \mathrm{ml})$ & $1,2,3,4$ \\
\hline Aooo & Domestic & No.66 $(07 \mathrm{ml})$ & $1,2,3,4$ \\
\hline Booo & Domestic & No.44 $(12 \mathrm{ml})$ & $1,2,3,4$ \\
\hline Rooo & Domestic & No.76(11ml $)$ & $1,2,3$ \\
\hline Aooo & Foreign & No.76(11ml) & 2,4 \\
\hline
\end{tabular}

※ 1, Contents change; 2, Bottle change; 3, Packing change; 4, Brush kit change

\subsection{VCR recording}

충진 공정을 대상으로 표준 준비교체 작업을 $\mathrm{VCR}$ 로 촬영 하였다. 촬영의 시작은 $\mathrm{A}$ 제품 생산 완료 시점부터 $\mathrm{B}$ 제품 생 산 시작 시점까지 순간 끊김이 없이 연속으로 실시하였다. 작업 순서는 충진 노즐 위치 해체, 충진 실린더 및 부품 해 체, 부품 청소 및 세정, 충진 실린더 및 부품 조립, 내용물 충진, 충진 Jig 조립, 시험 토출(吐出) 등의 순으로 촬영하
였다. 촬영된 총 준비교체 시간은 22.1 분이었다.

\subsection{Work analysis and time measurement}

촬영된 준비교체 작업을 재생하여 작업분석 및 시간관측 을 실시하였다. 작업분석은 요소작업 분석을 실시하였고 작 업시간을 측정하였다. 다음으로 분석내용을 작업의 주 목적 기준으로 준비, 교체, 조정작업 세 가지로 분류하였다. 준비 작업은 교체와 조정작업을 위한 사전 준비작업과 교체와 조 정작업 후 마무리 작업 및 작업 중간에 도구(Tool), 기구 (Fixture), 수공구(Hand Tool) 및 재료(Material) 들의 준 비작업에 관한 내용을 주 목적으로 정의하였다. 교체작업은 재료, 부품, 금형, 지그, 도구, 기구, 가공조건 등을 교체하는 것으로 차기 제품 생산을 위한 생산 4요소 중 3요소(재료, 설비, 방법)에 관련된 모든 작업내용의 변경으로 장착(裝着), 조립(組立) 과 탈착(脫着), 분해(分解)로 정의하였다. 조정은 교체작업 1 회 완료 전, 후에 발생하는 추가 작업으로 위치설 정, 중심조정, 검사, 재검사 등의 작업으로 정의하였다. 이와 같은 기준으로 분석된 요소작업 수는 준비 102개, 교체 81 개, 조정 21 개로 총 204 개의 요소작업으로 분류되었다.

\subsection{Motion analysis}

작업분석에서 분석된 요소작업 단위를 기준으로 Table 2 의 17 가지 서어블릭 기호를 사용하여 발생된 동작 빈도 수 를 측정하였다(Whang, 1987). 측정된 총 2,448 개의 동작 은 준비작업 1,074 개, 교체작업 1,198 개 그리고 조정작업 176 개로 측정되었다.

Table 2. Therblig symbols

\begin{tabular}{c|c|c|c}
\hline Therblig & Symbol & Therblig & Symbol \\
\hline Search & Sh & Inspect & I \\
\hline Select & St & Assemble & A \\
\hline Grasp & G & Disassemble & DA \\
\hline Transport empty & TE & Use & U \\
\hline Transport loaded & TL & Un-avoidable delay & UD \\
\hline Hold & H & Avoidable delay & AD \\
\hline Release load & RL & Plan & Pn \\
\hline Position & P & Rest for overcoming & fatigue \\
\hline Pre-position & PP & R &
\end{tabular}

\subsection{REBA analysis}

작업부담 위험수준 측정은 의자에 앉아서 일하는 작업이 
아니라 상체와 하지를 전부 사용하는 작업이므로 REBA을 사용하였다(Hignett and McAtamney, 2000). 촬영된 준 비교체 작업을 요소작업으로 분석한 결과 총 204개로 분석 되었다. 요소작업의 평균시간은 6.5 초이며 최대 38 초, 최소 1 초, 표준편차는 5.31 초였다. 각 요소작업의 대표 작업자 세 선정은 작업빈도, 요소작업 시간 내에서 시간비율, 작업 부하가 높은 자세로 추출하였다(McAtamney and Corlett, 1993). 측정은 Score A, Score B, Score C, REBA Score 로 측정하였으며, 그 데이터들은 준비, 교체, 조정작업으로 분류되었다.

\subsection{Statistical analysis}

종속변수로는 준비교체 작업에서 분류된 준비, 교체, 조정 작업으로 독립변수는 요소작업에서 측정된 소요시간, 서어블 릭 기호 동작 수, REBA Score로 정하였다. 독립변수들이 종속변수에 미치는 영향을 통계적으로 검증하기 위하여 유 의수준 0.05 로 한 일원배치 분산분석을 실시하였다. 자료의 통계분석은 Minitab 14을 사용하였다.

\section{Results}

\subsection{Motion analysis of element work}

각 요소작업에서 측정된 총 2,448 개의 동작을 Figure 2 와 같이 준비, 교체, 조정작업으로 분류하여 서어블릭 기호 의 발생 빈도 수를 대상으로 일원배치 분산분석을 실시한 결 과는 아래와 같다.

준비작업에서 서어블릭 동작 기호를 사용한 분석 결과 발 생 빈도가 높은 동작 기호는 $\mathrm{U}$ (사용한다)가 240개, TL(물

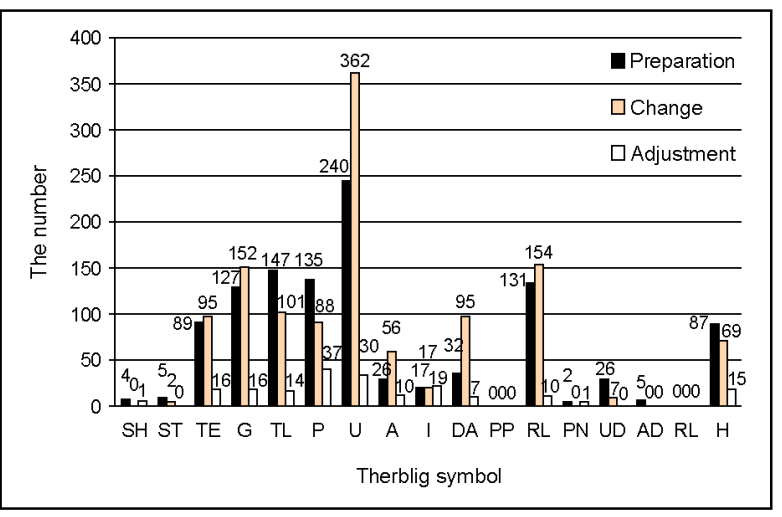

Figure 2. The number of therblig motions in the preparation work, the change work, and the adjustment work
건을 운반)이 147 개, $\mathrm{P}$ (위치를 정한다)는 135 개, $\mathrm{RL}$ (물건 을 놓는다)이 131 개, $\mathrm{G}$ (물건을 쥔다)는 127 개, $\mathrm{TE}$ (빈손을 이동)는 89 개, $\mathrm{H}$ (물건을 잡고 있다)가 87 개 $(F(16,1717)$ $=15.30, p=0.0001)$ 등의 순으로 각 동작은 통계적으로 유의한 차이를 나타냈다. 이는 교체, 조정작업 전후에 공구, 지그, 교체부품 등을 사용, 운반, 취급, 핸들사용, 제자리에 돌려두는 요소작업에서 발생하였다.

교체작업에서도 각 서어블릭 동작 기호를 사용하여 발생 빈도를 분석하였다. 발생 빈도가 높은 동작은 $\mathrm{U}$ (사용한다) 가 362 개, RL (물건을 놓는다)이 154 개, $\mathrm{G}$ (물건을 쥔다)는 152 개, TL(물건을 운반)이 101개, TE(빈손을 이동) 와 DA (물건을 분리한다)는 89 개, $\mathrm{P}$ (위치를 정한다)는 88 개, $\mathrm{H}$ (물 건을 잡고 있다) 가 69 개 $(F(16,1360)=14.18, p=0.0001)$ 등으로 각 동작은 통계적으로 유의한 차이가 있음을 보였다. 이 동작들은 주로 공구를 사용하여 지그, 교체부품 등을 교 체하는 작업으로 사용하거나, 잡고, 조립, 분해, 놓고, 제자리 에 돌려두는 요소작업에서 발생하였다. 준비작업과의 차이는 $\mathrm{TL}$ (물건을 운반), $\mathrm{P}$ (위치를 정한다)는 작았으며, $\mathrm{DA}$ (물건 을 분리한다)와 $\mathrm{A}$ (물건을 조립한다)가 상대적으로 많이 발 생하였다.

또한, 조정작업도 각 서어블릭 동작 기호를 사용하여 발생 빈도를 분석하였다. 발생 빈도 높은 동작은 $\mathrm{P}($ 위치를 정한 다) 가 37 개, $\mathrm{U}$ (사용한다) 는 30 개 $(F(16,340)=3.26, p=$ $0.0001)$ 등의 순서로 각 동작들은 통계적으로 유의한 차이 를 나타냈다. 조정은 준비, 교체작업보다는 상대적으로 작은 빈도 수로 나타났으며, 주로 확인, 교체조립 후 재 조립, 위 치를 조정하는 요소작업이었다.

\subsection{Average motion time of element work}

준비교체 작업을 총 204 개의 요소작업으로 분석한 후 각 요소작업에 대하여 소요시간을 측정한 결과 총 1,329 초로 측정되었다. 요소작업 수와 소요시간은 준비작업이 102 개로 629 초이며, 교체작업은 81개로 535초, 그리고 조정작업 21 개로 165 초로 측정되었다. 다음으로 각 요소작업 별로 측정된 시간을 동작 발생 빈도 수로 나눈 동작 평균시간을 산출하였다. 이 데이터를 준비, 교체, 조정작업으로 분류하 고 일원배치 분산분석을 실시하였다. 그 결과 Figure 3 과 같 이 평균 동작시간은 조정이 1.85 초, 준비가 1.11 초, 교체는 0.62 초 $(F(2,201)=7.04, p=0.001)$ 순으로 각 평균 동작 시간은 통계적으로 유의한 차이를 나타냈다. 이는 조정작업 에서 눈으로 상태를 확인, 버튼 조작으로 시험 토출 등의 요 소작업 시간이 길고 상대적으로 동작 수는 작게 나타났다. 준비작업은 지그, 도구 등을 운반, 이동하는 요소작업으로 시간에 비해 동작 수는 작게 발생되었다. 교체작업은 공구를 
사용하여 지그 또는 볼트 등을 조립, 분해하는 요소작업에서 준비, 조정작업 보다 상대적으로 동작 수가 많이 발생되었다.

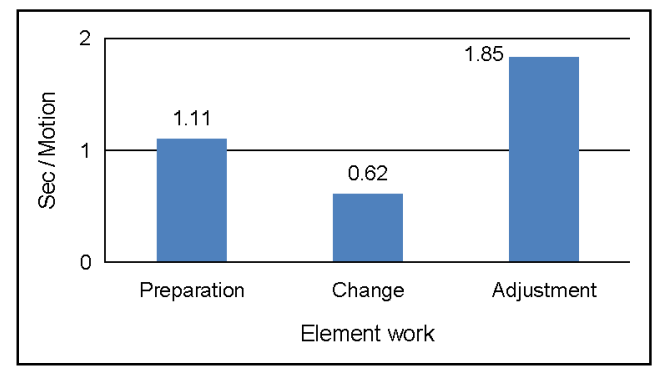

Figure 3. Average time by motion

\subsection{REBA analysis of element work}

$\mathrm{REBA}$ 분석은 요소작업으로 분석된 204가지를 준비, 교체, 조정작업으로 분류하였고, 각 요소작업에 대하여 Figure 4와 같이 대표 작업자세를 추출하여 분석을 실시하였다. 통계적 검증을 위해 독립변수 데이터 (Score A, Score B, Score C, $\mathrm{REBA}$ Score) 는 주 목적에 의해 분류한 종속변수에 미치는 영향을 분석하였다(Figure 5).

평균 Score A는 준비 3.18, 교체 4.06, 조정 4.19로 준비

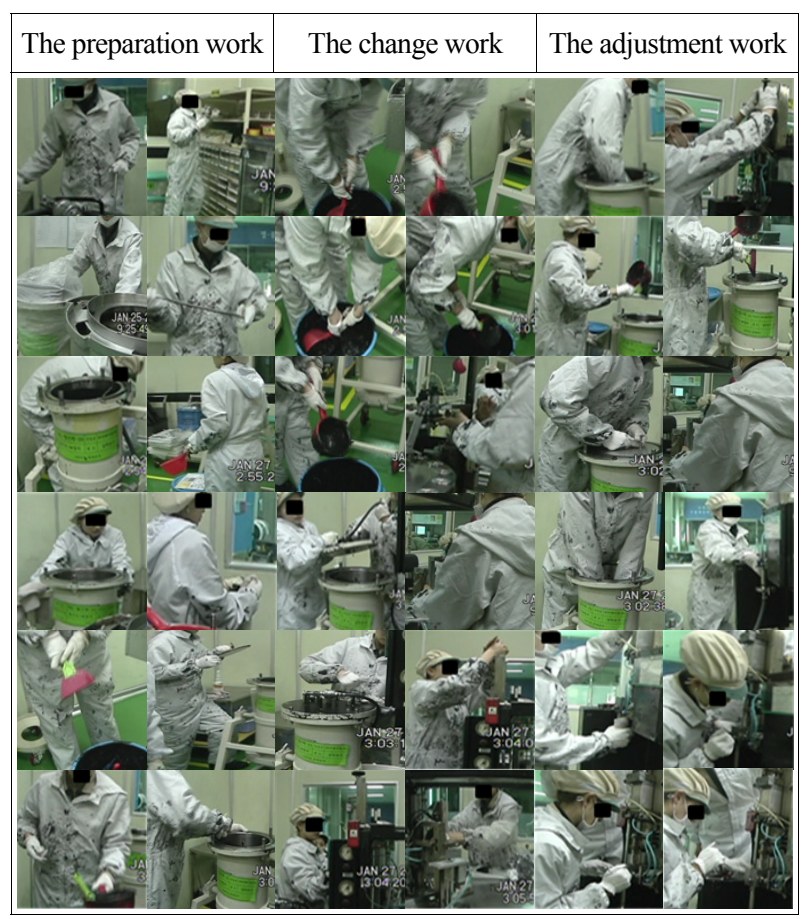

Figure 4. The typical working posture of element work (Example)

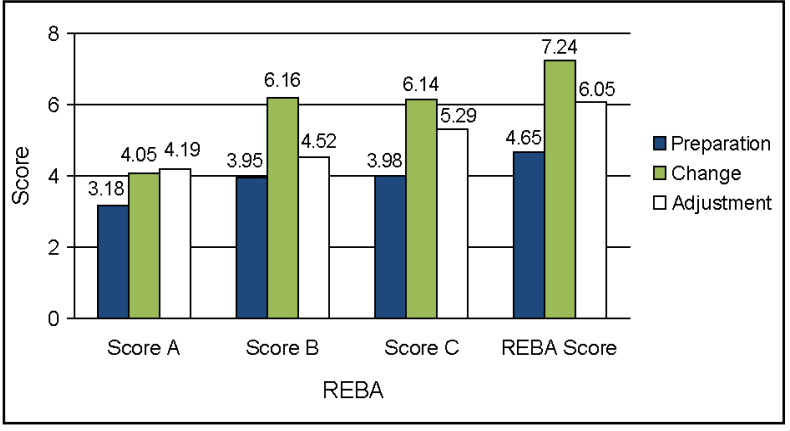

Figure 5. The result of REBA analysis

보다 교체와 조정이 통계적으로 높게 분석되었다 $(F(2,201)$ 7.00, $p=0.001)$. 그 이유는 허리와 목을 굽히거나 젖히 는 자세가 발생한 요소작업 비율이 크기 때문이었다. 평균 Score B는 준비 3.95, 교체 6.16, 조정 4.52이며 교체가 조 정과 준비작업 보다 크며 통계적으로 차이가 있었다 $(F(2$, 201) $=24.44, p=0.0001)$. 이는 어깨 중심의 위팔과 팔꿈 치 중심의 아래팔 그리고 손목의 각도가 큰 자세와 손잡이 형태에 의한 자세의 요소작업 비율이 많이 발생하였다. 평균 Score C는 준비 3.98, 교환 6.14, 조정 5.29이고 Score B 와 같이 교체가 조정과 준비작업 보다 크며 통계적으로 차 이가 있는 것으로 나타났다 $(F(2,201)=17.56, p=0.0001)$. 이는 교환과 조정작업에서 Score A의 허리와 목을 굽히거나 젖히는 자세와 Score $\mathrm{B}$ 의 위팔과 아래팔 그리고 손목의 각도가 큰 자세와 손잡이의 형태에 의한 자세가 동시에 발 생한 자세의 요소작업 비율이 크게 발생하기 때문이었다. 평 균 $\mathrm{REBA}$ Score는 준비 4.65, 교환 7.24, 조정 6.05이며 통계적으로 유의한 차이를 나타냈다 $(F(2,201)=18.77$, $p=0.0001)$. 이는 교환이 준비와 조정보다 불안전한 자세 의 요소작업 비율이 크기 때문이었다.

또한, 분석된 준비, 교체, 조정작업을 REBA Score가 8 이상의 위험수준이 높아 조치가 필요한(Action Level 3 이 상) 요소작업에 대한 점유율을 분석하였다. 그 결과 준비 $22.6 \%$, 교체 $53.1 \%$, 조정 $42.9 \%$ 로 교체, 조정, 준비 순으 로 나타났다. 준비작업에서 REBA Score을 증가시킨 작업 자세의 주요 작업내용은 내용물 긁어 모으기, 공구, 지그 및 기구 취급이었다. 주로 허리를 중심으로 몸통을 $60^{\circ}$ 이상 굽 혀 양손에 도구를 이용하여 용기 안의 벽과 바닥에 붙어 있 는 점도 높은 내용물 (마스카라)을 담기 위한 긁거나 모으는 작업이었다. 또 다른 자세는 손의 작업 점이 머리 위까지 올 려 작업하는 자세였다. 이 자세는 어깨를 중심으로 위팔이 $90^{\circ}$ 이상 들림과 아래팔이 0 60사이 들림으로 두 손목은 안으로 $15^{\circ}$ 이상 꺾임 상태에서 손의 부하가 $10 \mathrm{Kg}$ 이상의 힘으로 끌어 내리는 작업과 동일한 자세에서 핸들을 돌리는 
작업이었다. 교체작업에서 REBA Score을 높게 한 자세는 허리를 중심으로 몸통을 $60^{\circ}$ 이상 굽혀 양손에 도구를 이용 하여 용기 안의 점도가 높은 내용물 (마스카라)을 퍼내는 요 소작업이었다. 또 다른 자세는 퍼낸 내용물을 들어올려 투입 하는 자세로 위팔은 $45 \sim 90^{\circ}$ 사이와 아래팔은 0 60 사이 들림으로 두 손목은 안으로 $15^{\circ}$ 이상 들림 자세에서 손목을 돌려 내용물을 압력용기에 투입하는 요소작업이었다. 그리고 공구를 사용하여 볼트나 너트 등을 체결 또는 해체하는 자 세였다. 이 자세는 몸통은 20 60 앞으로 굽히고 목은 0 $20^{\circ}$ 을 뒤로 젖힌 상태에서 위팔은 $45 \sim 90^{\circ}$ 들고 아래팔은 0 60 $0^{\circ}$ 인 자세로 손목의 꺾임과 들림의 각도가 $15^{\circ}$ 이상이 고 비틀어짐이 발생되는 요소작업이었다. 분해 조립작업은 볼트나 너트를 체결 해체하는 요소작업과 유사한 자세에서 고착된 내용물로 인하여 손과 팔에 $10 \mathrm{~kg}$ 이상의 부하가 발 생하는 자세였다. 조정작업에서 REBA Score가 높은 요소 작업자세는 가압용기 안의 옮겨진 내용물을 수평으로 다지 거나, 가압 판 평면 상태를 조정하는 작업이었다. 이 자세는 몸통을 20 60 로 굽힌 상태에서 목을 앞으로 $20^{\circ}$ 이상 구 부림 자세로 손에는 $10 \mathrm{Kg}$ 이상의 부하가 가해지며 위팔은 45 90 $0^{\circ}$ 으로 어깨가 들려진 자세에서 아래팔은 0 60 사이 를 유지하고 손목은 $15^{\circ}$ 이상 꺾이거나 들림 상태의 요소작 업이었다. 또는 조립위치와 센터가 일치하지 않아 재 분해와 조립을 실시하는 작업자세로 분해 및 조립자세와 유사하였다.

\section{Discussion}

준비교체 작업을 준비, 교체, 조정으로 분류하고 각 요소 작업에 대하여 서어블릭 기호를 이용한 동작분석과 시간측 정 및 $\mathrm{REBA}$ 분석을 실시한 결과, 통계적으로 유의한 차이 가 있음을 알 수 있었다.

Shingo(1989)는 시간 단축 목표 중심의 개선 순서로 첫 째, 내 준비교체를 외 준비교체로 변경하는 것을 권고하였다. 둘째, 준비교체 작업을 준비, 교환, 조정작업으로 분류하고 개선하기 쉬운 준비작업 개선부터 실시할 것을 권고한다. 그 러나 첫째 방법은 외 준비교체 또한 작업자가 작업을 수행하 여야 하기 때문에 근본적인 해결책이라고 할 수 없다. 둘째 방법은 시간 단축의 효과는 있지만 작업자세 부하의 부담요 인은 고려하지 않고 있다. 그러므로 준비교체 작업을 수행하 는 작업자의 작업부하 수준의 향상 정도를 객관적으로 표현 하기가 어렵다.

따라서, 본 연구는 작업자세 부하의 부담요인을 제거함과 동시에 시간을 단축시키는 방향을 제시하고자 한다. 첫째 요 소작업 분석단위로 서어블릭 기호를 이용한 동작분석과 시
간측정으로 동작 소요시간을 구하여 평균 동작시간 이상 소 요되는 요소작업과 시간대비 동작 수가 많은 요소작업을 개 선한다. 둘째, REBA Score 8 이상인 요소작업을 중심으로 Score A와 Score B에서 작업자세 부하의 부담요인을 찾아 개선한다. 이 방법의 기대효과는 시간 단축과 작업부하 수준 을 낮출 수 있다. 이와 같은 방법으로 다음과 같이 개선방향 을 고찰하여 보았다.

준비작업에 대한 평균 동작시간은 1.11 초로 분석되었다. 평균 동작시간 보다 큰 동작시간의 요소작업들은 $23.5 \%$ 이 며 시간은 $31.5 \%$ 를 점유하고 있다. 이 작업들은 지그, 공구, 세척도구 등을 보관장소에서 가져오거나 두는 작업으로 운 반작업들이다. 이러한 작업은 준비교체 대차를 설계하여 작 업에 필요한 도구들을 세트로 운반하면 1회 운반작업 시간 을 최소화 시킬 수 있다. 또한 동작 수가 많이 발생하는 작 업 중 도구주변에 붙어 있는 내용물을 긁어 내기 위한 작업 은 내용물 보관통과 가압 통을 일체화시켜 작업을 삭제시키 는 방향으로 한다. REBA Score 8 이상인 23개의 요소작업 들은 대부분 내용물 보관통(높이 약 $70 \mathrm{Cm}$ ) 안에 허리를 굽 혀 내용물을 긁어 내리는 작업과 지그, 공구, 도구 등을 허리 를 굽혀 바닥에 있는 장소에서 집고 놓는 작업 그리고 손의 작업 점이 머리위로 올려 지그와 기구의 취급하는 작업자세 다. 이 작업자세를 개선하는 방향은 내용물 보관통과 가압 통을 일체화시킨다. 이 결과는 Score A에서 허리를 굽히고 머리를 뒤로 젖히는 자세와 Score $\mathrm{B}$ 에서 아래팔이 $0^{\circ}$ 을 유 지하면서 도구를 사용하는 손목의 부하자세를 해소할 수 있 을 것이다. 또한 지그, 공구, 도구를 준비교체 대차에 배치 하는 높이 설계 기준은 다음과 같이 산출한다. 최저높이는 허리를 굽히지 않고 위팔은 $0^{\circ}$ 아래팔은 $60^{\circ}$ 의 높이로 설 정하고 최고높이는 위팔 $20^{\circ}$ 아래팔은 $100^{\circ}$ 의 높이를 설 정하여 그 사이에서 손목의 들림이 없이 집고 놓을 수 있도 록 설계한다. 이러한 결과는 Score A의 허리를 굽히는 자 세와 Score B에서 위팔, 아래팔, 손목 등의 부하 자세를 해 소할 수 있다. 손의 작업 점이 머리 위까지 올려 작업하는 자세의 개선방향은 수직으로 설치된 지그와 기구의 작업 점 높이를 준비교체 대차의 최소높이와 최고높이의 설계방법으 로 산출된 높이 범위를 사용한다. 그 사이에 가로 형태로 지 그와 기구를 설치하여 Score B의 부하자세를 해소시키고 수 직으로의 작업 점까지의 거리는 1 2보를 걷는 작업으로 설 계한다.

교체작업에서의 평균 동작시간은 0.62 초로 분석되었다. 평균 동작시간 보다 큰 동작시간의 요소작업들은 $34.6 \%$ 이 고 시간은 $50.8 \%$ 을 점유하고 있다. 이 작업들은 볼트를 사 용하여 지그 및 기구를 가 조립, 체결, 분해하는 요소작업들 이었다. 이러한 작업의 개선방향은 볼트를 사용하지 않고 원 터치 부품을 사용하여 삭감시켜 조립 분해시간을 최소화 할 
수 있다. 동작 수가 많이 발생하는 작업은 내용물을 도구를 사용하여 퍼내는 작업과 가압용기에 투입하는 작업으로 내 용물 투입 완료까지 수회에 걸쳐 반복되는 요소작업들이다. 이 작업들의 개선방향은 내용물 보관통과 가압 통을 일체화 시켜 내용물 제조 후 직접 가압 통에 담아 보관 후 사용한다. 이 결과는 내용물을 옮기는 작업을 삭제시켜 작업시간을 단 축시킬 수 있다. REBA Score 8 이상인 요소작업 수는 43개 로 점유율은 $53.1 \%$ 를 나타냈다. 이 작업들은 대부분이 허리 를 굽혀 퍼내고 투입하는 작업과 볼트나 너트 등을 체결하거 나 해체하는 작업들이었다. 이 작업들의 개선방향도 내용물 저장통과 가압 통을 일체화하면 내용물 퍼내기와 투입작업 이 삭감될 수 있다. 그 결과 Score A와 Score B의 부하자 세를 해소할 수 있을 것이다. 볼트나 너트 등을 체결 또는 해체하는 작업들의 개선방향은 작업자의 몸통과 지그와 기 구에 대한 손의 작업 점의 거리를 줄여 몸통과 머리의 굽힘 을 0 20 $0^{\circ}$ 을 유지할 수 있게 하는 방법이다. 그리고 지그와 기구에 센터 라인과 기준면을 설정하고 중개지그와 원 터치 부품을 사용하는 것으로 설계한다. 이 결과들은 Score A의 몸통을 20 60 앞으로 굽히고 목은 0 20 $0^{\circ}$ 을 뒤로 젖히는 자세와 Score B에서 위팔은 45 90 들고 아래팔은 0 $60^{\circ}$ 인 자세 그리고 손목의 꺾임과 들림의 각도가 $15^{\circ}$ 이상 이고 비틀어짐의 부하자세를 해소할 수 있을 것이다.

또한, 조정작업은 평균 동작시간이 1.85 초로 분석되었다. 평균 동작시간 보다 큰 동작시간의 요소작업들은 $28.6 \%$ 이 며 시간은 $43.0 \%$ 를 점유하고 있다. 이 작업들은 눈으로 내 용물의 이동 상태를 확인하는 작업과 조립 위치를 확인하는 작업이었다. 이 작업들의 개선방향은 노즐 출구 측 끝 단에 광 센서를 설치여 내용물이 감지되면 내용물 공급 실린더 동 작을 스톱시키는 장치를 설치한다. 이 결과는 작업자가 눈으 로 감시하는 시간을 삭제할 수 있다. 그리고 센터 라인과 기 준면의 설정으로 지그와 기구의 조립부위의 위치를 공용화 하여 조정작업 시간을 삭감할 수 있는 방향으로 한다. REBA Score 8 이상인 요소작업 수는 9개로 점유율은 $42.9 \%$ 을 나타냈다. 이 작업들은 가압용기 안의 옮겨진 내용물을 수평 으로 다지거나, 가압 판 평면 상태를 조정하는 작업이었다. 이 작업들의 개선방향은 내용물 제조 후 배출온도에서 보관 기능과 가압기능을 일체화 시킨 가압 통에 직접 투입하면 점도가 묽은 상태이므로 내용물 면이 자동으로 수평을 이루 게 되므로 수평으로 다지는 작업을 개선할 수 있다. 또한 가 압 판을 수평으로 조정하는 이유는 가압 판과 내용물 면사이 의 공기가 배출되는 곳이 없으므로 수평으로 조정하는 작업 이 발생하므로 원형 가압 판 센터에 핀 홀을 설치하면 조정 없이 내용물 면까지 조립할 수 있다(가압 시는 나사 캡으로 밀폐시킴). 이 개선방향의 기대효과는 Score A의 몸통을 20 60 로 굽힌 상태에서 목을 앞으로 $20^{\circ}$ 이상 구부림과
손에 $10 \mathrm{Kg}$ 이상의 부하가 가해지는 자세부하와 Score B 의 위팔은 $45 \sim 90^{\circ}$ 으로 어깨가 들려진 자세에서 아래팔은 0 60 사이를 유지하고 손목은 $15^{\circ}$ 이상 꺾이거나 들림 상 태의 작업자세들을 제거할 수 있다.

따라서 본 연구결과에서 파악된 작업방법과 자세를 중심 으로 개선방향을 추진하면 $\operatorname{Kim}(2009)$ 이 연구한 작업부하 위험수준을 감소시킬 수 있으며, 그 결과 상대적으로 육체적 직무 요구도와 사회 심리적 스트레스 요인에 노출되는 경향 을 낮출 수 있다. 이는 비 부담작업으로 작업내용을 개선하 면 자율성이 높아져 준비교체 작업의 기피 현상 감소에 따 른 준수율 향상을 기대할 수 있고, 또한 준비교체 시간 단축 도 기대할 수 있다. 그러나 본 연구의 한계점은 현장의 1 개 공정에서 1 인이 작업하는 준비교체 작업으로 작업자가 느 끼는 불편도의 실험분석을 실시하지 못하였다(Park et al., 2006). 향후 필요한 연구계획으로는 본 연구 공정을 대상 으로 토의에서 제기된 개선방향을 해당 작업의 개선을 실시 하고 서어블릭 기호 동작발생 빈도, REBA Score, 교체시간 의 단축 정도를 비교하고자 한다.

\section{References}

Choi, G. I., Mun, I. K. and Giri, B. C., A Study on the Economic Lot Scheduling Problem under Imperfect Production Processes. The Korean Operations Research and Management Science Society, Korea Institute of Industrial Engineers, Spring Conference, (pp.125 -130), 2001.

Ben-Daya, M. and Hariga, M., Economic lot scheduling problem with imperfect processes, The Journal of the Operational Research Society, 51(7), 875-881, 2000.

Ham, H. J., Facilities Management Focused on Profitability, Dong Hyun Publishers, 2000.

Hignett, S. and McAtamney, L., Rapid Entire Body Assessment (REBA), Applied Ergonomics, 31(2), 201-205, 2000.

Kim, D. H. and Kim, S. B., JIT Production System of Domestic Manufacturing and It's Impact on Manufacturing Performance, Journal of the Society of Korea Industrial and System Engineering, 28(1), 64-72, 2005.

Kim, S. H., A Study on the Association between Job Stress and Musculoskeletal Workload in the Manufacturing Industry, The Ergonomics Society of Korea, 28(4), 25-34, 2009.

Kim, J. I. and Lee, Y. H., Batch Scheduling of Incompatible Job Families with Sequence Independent Setup Times, Korean Operations Research and Management Science Society, 26(2), 69-83, 2001.

Koo, I. S., Kim, T. S. and Mok, J. H., An Investigation on the TPS and New JIT, The Journal of Namseoul University, 11(2), 53-68, 2005.

McAtamney, L. and Corlett, E. N., RULA: a survey method for the 
investigation of work-related upper limb disorders. Applied Ergonomics, 24(2), 91-99, 1993.

Park, K. S., Kang, D. M., Lee, Y. H., Woo, J. H. and Shin, Y. C., Development of self administered questionnaire and validity evaluation for American National Standards Z-365 checklist. Journal of Korean Society Occupational Environmental Hygiene, 16(2), 172-182, 2006.

Park, J. K., Park, S. J. and Jung, E. S., Psychophysical Evaluation of Postural Stresses for Combined Task at Varying Working Time and Workload of Single Tasks. Journal of the Ergonomics Society of Korea, 25(1), 7-16, 2006.

Shingo, S., A Study of the Toyota Production System From an Industrial Engineering View Point, Japan management association, 1989.

Whang, A., Theory of Work Management, Youngji Publishers, 1987.
Peom Park: ppark@ajou.ac.kr

Highest degree: Ph.D., Iowa State U. Industrial \& Systems Engr. Position title: Professor, Industrial \& Information Systems Engr., Ajou U. Areas of interest: Human Factors, HCI, uHealthcare, Telematics system, uX Design, Industrial Safety system

Date Received : 2011-06-02

Date Revised : 2011-10-05

Date Accepted : 2011-10-05

\section{Author listings}

Sung Koon Lee: cellsg_lee@yahoo.co.kr

Highest degree: Ph.D. Department of Industrial Engineering, Ajou

University

Position title: Ph.D. Department of Industrial Engineering, Ajou

University

Areas of interest: Ergonomics, Work Design 